\title{
STUDENTS' ENGLISH SPEAKING ANXIETY BASED ON PERSONALITY TRAITS AT ISLAMIC BOARDING SCHOOL
}

Dessy Kurniasy

IAIN Langsa

dessyari09@yahoo.co.id

Rianty Susan

IAIN Langsa

Riasusanty36@gmail.com

\begin{abstract}
The title of this research is "Students' English Speaking Anxiety based on Personality Traits at Islamic Boarding School". This study was carried out to investigate English speaking anxiety experienced by students based on their personality traits (extrovert-introvert dimension) in boarding school. The method used in this study was quantitative approach with descriptive design. The population were 120 students in the fifth grade students of Madrasah Ulumul Qur'an Langsa where 92 students as the sample taken by using random sampling technique. The data were collected by "Mark Parkinson (1997) Personality Questioner" that consists of 16 statements and "Foreign Language Classroom Anxiety Scale (FLCAS)" by Horwitz. et.al (1986) that consists of 33 statements. The finding indicated that the percentage of students who exhibit each dimension of personality from the highest to the lowest; they were introvert dimension (ID) of personality $67,4 \%$ and extrovert dimension (ED) of personality $32,6 \%$. The result of English Speaking Anxiety level divided into five categories. There were 11 students or $12 \%$ in low level, 32 students or $34,8 \%$ in medium level, 47 students or $51,1 \%$ in high level, 2 students or 2,2 \% in very high level and there was no one in very low level of the English speaking anxiety. Based on these finding it can be concluded that English speaking anxiety of the students was high level range and introvert was the dominant personality dimension possessed by the students.
\end{abstract}

Keywords

Speaking Anxiety, Personality Traits (Extrovert-Introvert). 


\section{INTRODUCTION}

English competence is very necessary and put forward in the world of education. It is evident that in its development since 1967 the minister of education and culture issued a policy that English is officially taught as a foreign language in Indonesian schools. However, in the learning process does not always run smoothly where there are obstacles that hinder the fluency of language skills. This is in line withBailey and Savage's (1994) view that speaking English as a second language (L2) or as a foreign language (FL) is the most difficult language skill among the four other language skills. The problems that arise not only from the external aspects of less supportive of the material taught alone, but also derived from the internal aspects that comes from within the self. According to Krashen (1980) in learning English as a Foreign Language, psychological factors such as shyness, fear of wrong, lack of confidence, anxiety, and other effective factors affect the ability of one's language mastery. This fear and anxiety is termed as "language anxiety".

Floyd Allport (1924) stated that personality is the characteristic of social environment. May adds that personality is the social stimulus value of the individuals. Moreover, personality is usually studied through broad systems that attempt to explain functioning in all, at least, most areas of life and, in particular, abnormal behavior.Actually, personality is the habits and its system of social importance that are stable resistance to change. Among the factors mentioned above, researchers focused on the personalities and language anxieties in this study.

The level of anxiety in each person will vary. There are several factors that affect anxiety levels in a person include personality type, place of residence, age, and sex. Jung explains that personality is the supreme realization of the innate idiosyncrasy of a living being. He added that 
personality has types of attitude of individuals, there are extroverts and introverts group of students.Extrovert person tends to be active, sociable, easy-going, friendly, talkative, aggressive and a risk-taker, whereas introvert person tends to be passive, quiet, reserved, introspective, and seldom behaves in an aggressive manner.

In psychology perspective, extrovert and introvert are types of personalities that may influence students' motivation, the strategies they choose to learn language, classroom management and teaching language. Not only that, the personality types but also describes a person's self-condition in expressing what is being felt. Through the centuries, personality has been regarded as a practical force in determining success or failure in life. Personality takes on a role in every human action, ranging from anger, jealousy, happiness, sadness, even anxiety. These feelings arise outwardly according to the personality of each person. Both are bound to each other's relationships between those that influence and influenced.

There are many factors that affect and contribute to students' English performance include psychological factors. In this regard personality traits and foreign language anxiety are both interrelated. It could be assumed that the difference of students' foreign languages anxiety is influenced by their personality differences. The writer identifies some of the most influential aspects of foreign language anxiety. The factors are: students' personalities could be different, less vocabularies to increase idea, different levels of intelligence, study habits, and interest.

Students have great difficulty in speaking, so their performance levels are different. They receive and process information differently, there are differences in their personality traits and so does their understanding. It is often argued that a blend of personality characteristics is essential for people 
to succeed in their careers. Educators, researchers, and psychologists have been constantly searching for a series of abusive variables that predict patterns of student personality types and their relationship to academic performance. Personality has been recognized as the deciding factor of how people learn.

Between individual and other individuals may have a difference in the dominance of personality type especially if the individual is compared to the others in a population or social group. Of course differences in character and personality type will be more diverse. This is also the case in the fifth grade students of Madrasah Ulumul Qur'an (MUQ) Langsa community who are required to live in the school dormitory. It is a means for students in the learning process both in terms of language (English and Arabic), spiritual education, as well as objects of other studies that are Islamic. Dormitory is a means for students in the learning process both in terms of language (English and Arabic), spiritual education, as well as objects of other studies that are Islamic. This is supported also by the addition of new facilities issued by the the school Language Center that is published The Thematic Dictionary of English-Indonesian and Arab-Indonesian.

Although Madrasah Ulumul Qur'an is an Islamic Boarding School, there are some problems that are detected. In recent years the rate of use of foreign languages the school has been greatly reduced. This is based on several factors, one of the factors that come from within the students' selves that is English speaking anxiety which is also influenced by the personality traits of the students. 


\section{LITERATURE REVIEW}

\section{English Speaking Anxiety}

Anxiety is a condition that can come in a variety in different form. Spilberger (1983) views anxiety as an unpleasant emotional state or condition which is characterized by subjective feelings of tension, apprehension, and worry by activation or arousal of the autonomic nervous system. He states that there are two kinds of anxiety as follows:

First, state anxiety. It means emotional conditions states that will be high on the level if it is on the dangerous condition. In state anxiety, the people feel subjectivity, and they feel afraid, worry and nervous that is related on the active of otonom neuro system. It means that the anxiety of students in speaking, especially in conveying opinions. It happened on specific condition that can be dangerous for students. Second, trait anxiety. It influences of reflection from the old experiences in some conditionsthat can determine the different of individual.

Foreign language anxiety is defined by some authors as "a feeling of tension, apprehension and nervousness associated with the situation of learning a foreign language". Horwitz et. al., (1986) discussed foreign language anxiety as a distinct complex of self-perception, beliefs, and behaviors related to classroom language learning arising from the uniqueness of the language learning process.

English speaking anxiety is a feel of nervous, afraid, doubt when she or he answers questions in English lesson.Anxiety is a general term for several disorders that cause nervousness, fear, apprehension, and worrying. These disorders affect how we feel and behave, and they can manifest real physical symptoms. Students that are in anxiety having low-confident, 
embarrassment, shaky voice, rapid heartbeat, sweating, difficulty in speaking, dizziness, feeling weak and afraid of being laughed.

\section{The Factors Affecting English Speaking Anxiety}

Problem anxiety may be caused by a mental condition, a physical condition, and the effects of drugs or from a combination of these. Anxiety is considered a problem when symptoms interfere with a person's ability to sleep or otherwise function. Generally speaking, anxiety occurs when a reaction is out of proportion with what might be normally expected in a situation. Environmental factors that are known to cause several types of anxiety include:

a. Trauma from events such as abuse, victimization, or the death of a loved one

b. Trauma Stress in a personal relationship, marriage, friendship, and divorce

c. Stress at work

d. Stress from school

e. Stress finances and money

f. Stress from a natural disaster

g. Lack of oxygen in high altitude areas.

\section{Aspects of Speaking Anxiety}

Language anxiety is caused by various causes during learning process. The primary sources of language anxiety, stated by Horwitz and Cope (1986) are:

a. communication apprehension (the fear of communicating with other people), 
b. test anxiety (fear of exams, quizzes, and other assignments used to evaluate students' performance) or apprehension over academic evaluation,

c. fear of negative evaluation (worry about how others view the speaker).

\section{Communication Apprehension}

Communication apprehension arises from someone'se fear and shyness" if they have to communicate with others. In communication apprehension, people usually afraid of oral communication that is about speaking and listening. They will get difficulty to understand what people are saying and to make someone understands what they purpose to say. For example, when the students have to speak English with the teacher in the class, he or she may be anxious and afraid to speak in English or he may not understand what the teacher is saying. Moreover, the students will not feel confidence when they have to say something to the others because they are too afraid to talk with English.

\section{Test Anxiety}

Wu and Chan (2004) argue that test anxiety can occur when students have poor performance in the previous test. The students develop a negative stereotype about tests and they have irrational perceptions in evaluative situation. It means that test anxiety is related to someone's fear of test-taking situation. The students tend to deal with test anxiety every time they got to face frequent test. Mayer states that every student understands that taking a test means she will be graded, judged, and compared to her classmates, and that performing will get negative consequence from her teacher and parents. $\mathrm{He}$ also mentions that children with test anxiety can experience any number of physical, mental, and emotional symptoms, which can vary. Physical 
symptoms includes shortness of breath, heart palpitations, chest tightening, or sore throat, stomachache, vomiting, or diarrhea, shaky limbs and trembling, headache and body aches. Those symptoms will lose students ${ }^{e e}$ concentration on the test material, then they are getting difficult to finish their test because accidentally they forget the material of the test that has been remembered before.

\section{Fear of Negative Evaluation}

Fear of negative evaluation is the apprehension about other evaluations which may include avoidance of evaluative situation and the expectations that other might evaluate them negatively. Moreover, Young argues that in his survey on students ${ }^{\text {ee }}$ perspective on anxiety and speaking in the foreign language, many students reported that they would be more willing to speak if they were not too afraid of making a mistake and being evaluated negatively in front of their teacher and their peer. It means that if the students are not sure of what they are saying, they will feel fear of negative evaluation from others and also feel anxious because they do not want to look stupid in front of others.

\section{Personality Traits}

Mann (1959) states that personality is the most characteristic integration of an individual structure, mode of interests, behavior, capacities, abilities and attitudes. Jung (1934) adds that personality is the supreme realization of the innate idiosyncrasy of a living being. It is an act of high courage flung in the face of life, the absolute affirmation of all that constitutes the individual, the most successful adaptation to the universal condition of existence coupled with the greatest possible freedom for selfdetermination. He added that personality has types according attitude of individuals, those are extrovert and introvert. 


\section{Factors Influencing of Personality}

Many factors that affect development of a personality: 1. biological factors. 2. social factors. 3. cultural factors. 4. family factors. 5. situational factors.

Those factor, however, are important to know that many factors that affect development of a personality. The factors will be a significant effect for students personality which encourage the students' English speaking anxiety. Those factors can help the teacher know the different characteristic of each student in the classroom.

\section{RESEARCH METHOD}

Quantitative approach was used in this research. Quantitative approach is an approach in research where the data which is produced is in form numeral and the analysis use statistic. The design of this research is descriptive design where we are purposed to give indications, facts, or events systematically and accurately about certain population as stated by Sugiyono (2010).

The population in this research is the fifth grade students of Madrasah Ulumul Qur'an Langsa that consists of 6 classesMeanwhile, the sample of this research will be taken by using random sampling due to the population of the research are homogenous. The writer will take sample randomly with by choosing only 92 students as the sample by using Slovin formula with margin error 5 percent. 


$$
\begin{gathered}
n=\frac{N}{1+N\left(e^{2}\right)} \\
n=\frac{120}{1+120\left(5 \%^{2}\right)} \\
n=\frac{120}{1+0,30} \\
n=\frac{120}{1,30} \\
\boldsymbol{n}=\mathbf{9 2 , 3 0}
\end{gathered}
$$

$\mathrm{n} \quad=$ number of samples

$\mathrm{N}=$ number of population

e $\quad=$ limit error tolerance $(1 \%, 5 \%, 10 \%)$

To measure level of foreign language anxiety, the writer used Foreign Language Classroom Anxiety Scale (FLCAS) developed by Horwitz (1986). This scale consists of 33 statements consist of three aspects, such as: communication apprehension, test anxiety and fear of negative evaluation. Statements of each instrumentsconsists of two kinds of statements. There are favorable and unfavorable statements. Favorable statement is a statement that support the theory while unfavorable is a statement does not support the theory. These statements are arranged randomly. It is commonly seen as a 5-points scale ranging from "Strongly Agree, Agree, Undecided, Disagree, and Strongly Disagree". Each level in the scale is assigned a numeric value, usually started at 1 and increased by one for each level. It is important that these statements constitute a representative sample of all the possible opinions or attitudes about the object. In this research uses 4-points scale, this done to get accurate answers and to eliminate uncertain. 
Table I

Aspects of measurement Foreign Language Anxiety

\begin{tabular}{|c|c|c|c|c|}
\hline \multirow[t]{2}{*}{ No. } & \multirow[b]{2}{*}{ Aspects } & \multicolumn{2}{|c|}{ Number Item } & \multirow[b]{2}{*}{$\begin{array}{l}\text { Total } \\
\text { Item }\end{array}$} \\
\hline & & Favourable & Unfavourable & \\
\hline 1. & $\begin{array}{l}\text { Communication } \\
\text { Apprehension }\end{array}$ & $\begin{array}{c}1,4,9,15,24,27, \\
29,30\end{array}$ & $14,18,32$ & 11 \\
\hline 2. & Test Anxiety & $\begin{array}{c}3,6,10,12,16,17 \\
20,21,25,26\end{array}$ & $5,8,11,22,28$ & 15 \\
\hline 3. & $\begin{array}{l}\text { Fear of Negative } \\
\text { Evaluation }\end{array}$ & $\begin{array}{c}7,13,19,23,31 \\
33\end{array}$ & 2 & 7 \\
\hline
\end{tabular}

\section{FINDING AND DISCUSSION}

In this study, the writer found the result of students' extrovertintrovert personality and their English speaking anxiety. The result of the questionaries in this study were presented as follow:

\section{The result of Extrovert-Introvert Personality}

In the total of 92 students who were participants, it was found that the highest extrovert score was (11) and the highest introvert score was (-9).

\section{Table II}

The result of Extrovert-Introvert Personality

\begin{tabular}{|c|c|c|c|c|}
\hline Students' & $\begin{array}{c}\text { ED } \\
\text { Number }\end{array}$ & $\begin{array}{c}\text { ID } \\
\text { Score }\end{array}$ & $\begin{array}{c}\text { Total } \\
\text { Score }\end{array}$ & Qualification \\
\hline S1 & 6 & -9 & -3 & leaned to the introvert dimension \\
\hline S2 & 6 & -9 & -3 & leaned to the introvert dimension \\
\hline S3 & 10 & -5 & 5 & leaned to the extrovert dimension \\
\hline
\end{tabular}




\begin{tabular}{|c|c|c|c|c|}
\hline S4 & 11 & -6 & 5 & leaned to the extrovert dimension \\
\hline S5 & 4 & -11 & -7 & leaned to the introvert dimension \\
\hline S6 & 6 & -8 & -2 & leaned to the introvert dimension \\
\hline S7 & 5 & -10 & -5 & leaned to the introvert dimension \\
\hline S8 & 5 & -10 & -5 & leaned to the introvert dimension \\
\hline S9 & 4 & -10 & -6 & leaned to the introvert dimension \\
\hline S10 & 3 & -11 & -8 & leaned to the introvert dimension \\
\hline S11 & 3 & -10 & -7 & leaned to the introvert dimension \\
\hline S12 & 8 & -9 & -1 & leaned to the introvert dimension \\
\hline S13 & 2 & -9 & -7 & leaned to the introvert dimension \\
\hline S14 & 2 & -11 & -9 & leaned to the introvert dimension \\
\hline S15 & 2 & -7 & -5 & leaned to the introvert dimension \\
\hline S16 & 2 & -9 & -7 & leaned to the introvert dimension \\
\hline S17 & 4 & -8 & -4 & leaned to the introvert dimension \\
\hline S18 & 10 & -7 & 3 & leaned to the extrovert dimension \\
\hline S19 & 3 & -10 & -7 & leaned to the introvert dimension \\
\hline S20 & 5 & -6 & -1 & leaned to the introvert dimension \\
\hline S21 & 10 & -6 & 4 & leaned to the extrovert dimension \\
\hline S22 & 6 & -12 & -6 & leaned to the introvert dimension \\
\hline S23 & 4 & -10 & -6 & leaned to the introvert dimension \\
\hline S24 & 9 & -10 & -1 & leaned to the introvert dimension \\
\hline S25 & 11 & -3 & 8 & leaned to the extrovert dimension \\
\hline S26 & 9 & -3 & 6 & leaned to the extrovert dimension \\
\hline S27 & 5 & -11 & -6 & leaned to the introvert dimension \\
\hline S28 & 12 & -1 & 11 & leaned to the extrovert dimension \\
\hline S29 & 5 & -6 & -1 & leaned to the introvert dimension \\
\hline S30 & 4 & -8 & -4 & leaned to the introvert dimension \\
\hline S31 & 3 & -5 & -2 & leaned to the introvert dimension \\
\hline S32 & 8 & -11 & -3 & leaned to the introvert dimension \\
\hline S33 & 4 & -11 & -7 & leaned to the introvert dimension \\
\hline S34 & 8 & -5 & 3 & leaned to the extrovert dimension \\
\hline S35 & 10 & -4 & 6 & leaned to the extrovert dimension \\
\hline S36 & 6 & -10 & -4 & leaned to the introvert dimension \\
\hline S37 & 3 & -10 & -7 & leaned to the introvert dimension \\
\hline S38 & 2 & -11 & -9 & leaned to the introvert dimension \\
\hline
\end{tabular}




\begin{tabular}{|c|c|c|c|c|}
\hline S39 & 4 & -8 & -4 & leaned to the introvert dimension \\
\hline S40 & 9 & -4 & 5 & leaned to the extrovert dimension \\
\hline S41 & 5 & -7 & -2 & leaned to the introvert dimension \\
\hline S42 & 7 & -10 & -3 & leaned to the introvert dimension \\
\hline S43 & 8 & -6 & 2 & leaned to the extrovert dimension \\
\hline S44 & 11 & -4 & 7 & leaned to the extrovert dimension \\
\hline S45 & 6 & -8 & -2 & leaned to the introvert dimension \\
\hline S46 & 8 & -5 & 3 & leaned to the extrovert dimension \\
\hline S47 & 10 & -6 & 4 & leaned to the extrovert dimension \\
\hline S48 & 5 & -7 & -2 & leaned to the introvert dimension \\
\hline S49 & 8 & -5 & 3 & leaned to the extrovert dimension \\
\hline S50 & 5 & -11 & -6 & leaned to the introvert dimension \\
\hline S51 & 5 & -11 & -6 & leaned to the introvert dimension \\
\hline S52 & 13 & -7 & 6 & leaned to the extrovert dimension \\
\hline S53 & 8 & -5 & 3 & leaned to the extrovert dimension \\
\hline S54 & 1 & -8 & -7 & leaned to the introvert dimension \\
\hline S55 & 2 & -9 & -7 & leaned to the introvert dimension \\
\hline S56 & 5 & -9 & -4 & leaned to the introvert dimension \\
\hline S57 & 4 & -11 & -7 & leaned to the introvert dimension \\
\hline S58 & 9 & -11 & -2 & leaned to the introvert dimension \\
\hline S59 & 4 & -10 & -6 & leaned to the introvert dimension \\
\hline S60 & 2 & -11 & -9 & leaned to the introvert dimension \\
\hline S61 & 4 & -8 & -4 & leaned to the introvert dimension \\
\hline S62 & 6 & -10 & -4 & leaned to the introvert dimension \\
\hline S63 & 8 & -3 & 5 & leaned to the extrovert dimension \\
\hline S64 & 4 & -9 & -5 & leaned to the introvert dimension \\
\hline S65 & 7 & -9 & -2 & leaned to the introvert dimension \\
\hline S66 & 7 & -5 & 2 & leaned to the extrovert dimension \\
\hline S67 & 10 & -2 & 8 & leaned to the extrovert dimension \\
\hline S68 & 8 & -7 & 1 & leaned to the extrovert dimension \\
\hline S69 & 5 & -9 & -4 & leaned to the introvert dimension \\
\hline S70 & 2 & -11 & -9 & leaned to the introvert dimension \\
\hline S71 & 4 & -10 & -6 & leaned to the introvert dimension \\
\hline S72 & 6 & -8 & -2 & leaned to the introvert dimension \\
\hline S73 & 9 & -7 & 2 & leaned to the extrovert dimension \\
\hline
\end{tabular}




\begin{tabular}{|c|c|c|c|c|} 
S74 & 6 & -4 & 2 & leaned to the extrovert dimension \\
\hline $\mathrm{S} 75$ & 9 & -5 & 4 & leaned to the extrovert dimension \\
\hline $\mathrm{S} 76$ & 10 & -4 & 6 & leaned to the extrovert dimension \\
\hline $\mathrm{S} 77$ & 7 & -11 & -4 & leaned to the introvert dimension \\
\hline $\mathrm{S} 78$ & 6 & -7 & -1 & leaned to the introvert dimension \\
\hline $\mathrm{S} 79$ & 9 & -5 & 4 & leaned to the extrovert dimension \\
\hline $\mathrm{S} 80$ & 5 & -9 & -4 & leaned to the introvert dimension \\
\hline $\mathrm{S} 81$ & 4 & -9 & -5 & leaned to the introvert dimension \\
\hline $\mathrm{S} 82$ & 6 & -12 & -6 & leaned to the introvert dimension \\
\hline $\mathrm{S} 83$ & 3 & -11 & -8 & leaned to the introvert dimension \\
\hline $\mathrm{S} 84$ & 6 & -10 & -4 & leaned to the introvert dimension \\
\hline $\mathrm{S} 85$ & 8 & -7 & 1 & leaned to the extrovert dimension \\
\hline $\mathrm{S} 86$ & 11 & -6 & 5 & leaned to the extrovert dimension \\
\hline $\mathrm{S} 87$ & 8 & -6 & 2 & leaned to the extrovert dimension \\
\hline $\mathrm{S} 88$ & 5 & -12 & -7 & leaned to the introvert dimension \\
\hline $\mathrm{S} 89$ & 4 & -7 & -3 & leaned to the introvert dimension \\
\hline $\mathrm{S} 90$ & 7 & -9 & -2 & leaned to the introvert dimension \\
\hline $\mathrm{S} 91$ & 9 & -6 & 3 & leaned to the extrovert dimension \\
\hline $\mathrm{S} 92$ & 4 & -9 & -5 & leaned to the introvert dimension \\
\hline
\end{tabular}

*ED score: Extrovert Dimension

*ID score: Introvert Dimension

$(+)$ score: leaned to extrovert

(-) score: leaned to introvert

\section{The result of Students' English Speaking Anxiety}

The total of 92 respondents who fill the English speaking anxiety questionnair produce varied numbers. The lowest anxiety score obtained by students is 58 and the highest anxiety score is 109 . So from the scores obtained by the students, the anxiety experienced by the students can be grouped into several categories including: very low, low, medium, high, and very high. 


\section{Table III}

The result of Students' English Speaking Anxiety

\begin{tabular}{|c|c|c|}
\hline $\begin{array}{l}\text { Students' } \\
\text { Number }\end{array}$ & $\begin{array}{l}\text { Total } \\
\text { Score }\end{array}$ & Qualification \\
\hline S1 & 93 & High \\
\hline S2 & 103 & High \\
\hline S3 & 70 & Low \\
\hline $\mathrm{S} 4$ & 93 & Medium \\
\hline S5 & 97 & High \\
\hline S6 & 100 & High \\
\hline $\mathrm{S} 7$ & 88 & Medium \\
\hline S8 & 74 & Low \\
\hline S9 & 96 & High \\
\hline $\mathrm{S} 10$ & 97 & High \\
\hline S11 & 101 & High \\
\hline $\mathrm{S} 12$ & 97 & High \\
\hline $\mathrm{S} 13$ & 99 & High \\
\hline S14 & 99 & High \\
\hline $\mathrm{S} 15$ & 106 & High \\
\hline S16 & 90 & Medium \\
\hline S17 & 101 & High \\
\hline S18 & 72 & Low \\
\hline S19 & 63 & Medium \\
\hline S20 & 78 & Medium \\
\hline $\mathrm{S} 21$ & 84 & Medium \\
\hline S22 & 58 & Low \\
\hline $\mathrm{S} 23$ & 81 & Medium \\
\hline S24 & 91 & High \\
\hline S25 & 82 & Medium \\
\hline S26 & 101 & High \\
\hline S27 & 104 & High \\
\hline S28 & 68 & Low \\
\hline S29 & 76 & Medium \\
\hline
\end{tabular}




\begin{tabular}{|c|c|c|}
\hline S30 & 90 & Medium \\
\hline S31 & 82 & Medium \\
\hline S32 & 94 & High \\
\hline S33 & 78 & Medium \\
\hline S34 & 93 & High \\
\hline S35 & 79 & Medium \\
\hline S36 & 96 & High \\
\hline S37 & 97 & High \\
\hline S38 & 92 & High \\
\hline S39 & 82 & Medium \\
\hline S40 & 66 & Low \\
\hline S41 & 70 & Low \\
\hline S42 & 88 & Medium \\
\hline $\mathrm{S} 43$ & 103 & High \\
\hline S44 & 81 & Medium \\
\hline S45 & 92 & High \\
\hline S46 & 92 & High \\
\hline S47 & 95 & High \\
\hline S48 & 88 & Medium \\
\hline S49 & 84 & Medium \\
\hline S50 & 85 & Medium \\
\hline S51 & 96 & High \\
\hline S52 & 79 & Medium \\
\hline S53 & 92 & High \\
\hline S54 & 89 & Medium \\
\hline S55 & 98 & High \\
\hline S56 & 99 & High \\
\hline S57 & 86 & Medium \\
\hline S58 & 95 & High \\
\hline S59 & 102 & High \\
\hline S60 & 101 & High \\
\hline S61 & 86 & Medium \\
\hline S62 & 93 & High \\
\hline S63 & 61 & Low \\
\hline S64 & 95 & High \\
\hline
\end{tabular}




\begin{tabular}{|l|c|c|} 
S65 & 91 & High \\
\hline S66 & 90 & Medium \\
\hline S67 & 75 & Medium \\
\hline S68 & 75 & Medium \\
\hline S69 & 86 & Medium \\
\hline S70 & 104 & High \\
\hline S71 & 95 & High \\
\hline S72 & 109 & Very High \\
\hline S73 & 93 & High \\
\hline S74 & 68 & Low \\
\hline S75 & 76 & Medium \\
\hline S76 & 78 & Medium \\
\hline S77 & 98 & High \\
\hline S78 & 108 & Very High \\
\hline S79 & 86 & Medium \\
\hline S80 & 105 & High \\
\hline S81 & 95 & High \\
\hline S82 & 91 & High \\
\hline S83 & 100 & High \\
\hline S84 & 93 & High \\
\hline S85 & 62 & Low \\
\hline S86 & 98 & High \\
\hline S87 & 87 & Medium \\
\hline S88 & 97 & High \\
\hline S89 & 98 & High \\
\hline S90 & 94 & High \\
\hline S91 & 84 & Medium \\
\hline S92 & 70 & Low \\
\hline & & \\
\hline
\end{tabular}




\section{Table IV}

\section{Description of Data}

Descriptive Statistics

\begin{tabular}{|l|r|r|r|r|r|r|}
\hline & \multicolumn{1}{|c|}{$\mathrm{N}$} & $\begin{array}{c}\text { Minimu } \\
\mathrm{m}\end{array}$ & $\begin{array}{c}\text { Maximu } \\
\mathrm{m}\end{array}$ & \multicolumn{2}{|c|}{ Mean } & $\begin{array}{c}\text { Std. } \\
\text { Deviation }\end{array}$ \\
\cline { 2 - 7 } & Statistic & Statistic & Statistic & Statistic & $\begin{array}{c}\text { Std. } \\
\text { Error }\end{array}$ & Statistic \\
\hline Personality & 92 & 1.00 & 2.00 & 1.6739 & .04914 & .47135 \\
Anxiety & 92 & 2.00 & 5.00 & 3.4348 & .07620 & .73086 \\
Valid N & 92 & & & & & \\
(listwise) & & & & & & \\
\hline
\end{tabular}

Based on the table above, it showed that the value of mean (the average values) of the data are 1,6739 for the personality and 3,4348 for the anxiety. The value of minimum score are 1 for the personality and 2 for the anxiety. The value of maximum score are 2 for the personality and 5 for the anxiety. Then, the value of standard deviation are 0,47135 for the personality and 0,73086 for the anxiety. To describe the result of this research in detail, the writer present and analysis the data in the following steps:

\section{Analysis of Extrovert and Introvert Personality}

The percentage of extrovert dimension (ED) of personality, the writer used this formula:

$$
\begin{aligned}
& P=\frac{F x}{N} \times 100 \% \\
& P=\frac{30}{92} \times 100 \% \\
& P=32,6 \%
\end{aligned}
$$


And the percentage of introvert dimension (ID) of personality used formula:

$$
\begin{aligned}
& P=\frac{F x}{N} \times 100 \% \\
& P=\frac{62}{92} \times 100 \% \\
& P=67,4 \%
\end{aligned}
$$

\begin{tabular}{|c|c|c|c|}
\hline No. & Category & Frequency (f) & Percentage $(\%)$ \\
\hline 1. & Extrovert & 30 & 32,6 \\
\hline 2. & Introvert & 62 & 67,4 \\
\hline \multicolumn{2}{|r|}{ Total } & 92 & 100 \\
\hline
\end{tabular}

\section{Table V}

Rate Percentage and Frequency of Students' Personality

Figure I

The Percentage Scores of Personality

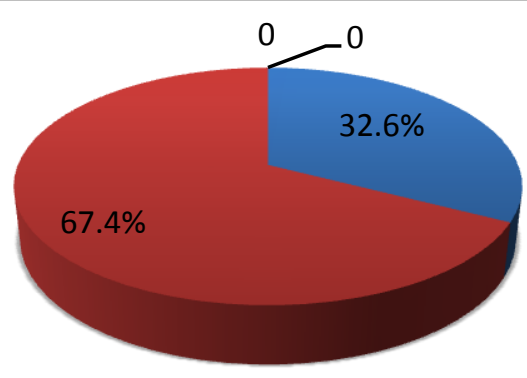

Extrovert

Introvert

Referring to the computation, the percentage of students who exhibit each dimension of personality from the highest to the lowest; they are 
introvert dimension (ID) of personality $67,4 \%$ and extrovert dimension (ED) of personality $32,6 \%$.

\section{Analysis of English Speaking Anxiety}

The result of English Speaking Anxiety level divided into five categories. There were 11 students or $12 \%$ in low level, 32 students or 3,8 \% in medium level, 47 students or $51,1 \%$ in high level, 2 students or $2,2 \%$ in very high level and there is no one in very low level of the English speaking anxiety. Percentage of the data present in diagram bellow:

Figure II

\section{The Percentage Scores of English Speaking Anxiety}

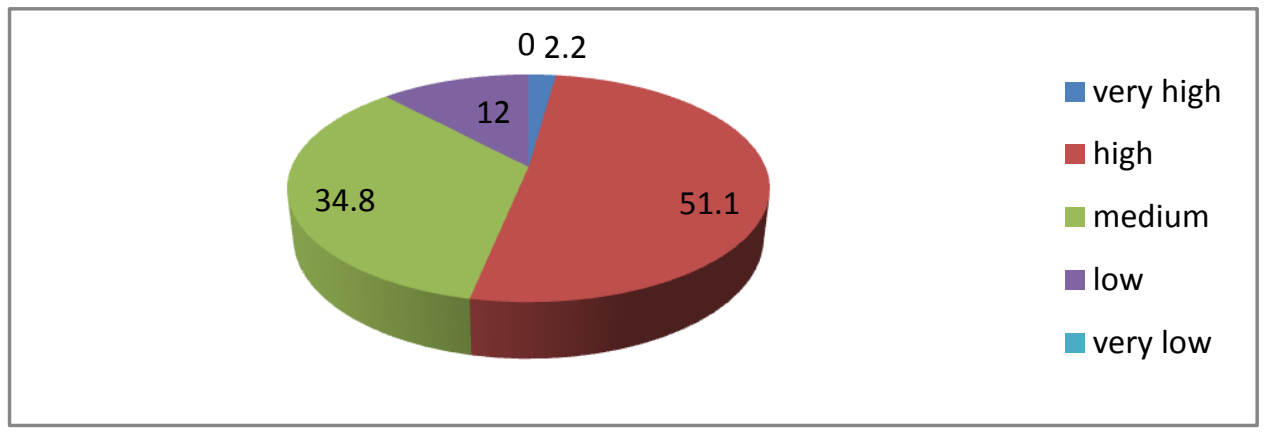

Hence, it can be concluded that the level of the seventh grade students of Madrasah Aliyah Ulumul Qur'an Langsa in English speaking anxiety were high.

The finding revealed that there were eleven (12\%) students in low level, thirty two (34\%) students in medium level, forty seven $(51,1 \%)$ students in high level , two (2,2\%) students in very high level of the English speaking anxiety. Based on the result, the level of English speaking anxiety of 
the seventh grade students in Madrasah Aliyah Ulumul Qur'an Langsa were high.

Based on the research statements, it had gotten additional information from the samples. Most of participants said that they were studying English since in Elementary school. Fifty one (54,34\%) students said that they were never speak in large group such as speech contest. They said that they were nervous, unconfident and embarrassed. Most of the participants responded that they were very concern about having to speak in front of the class. While thet other said that they started to be panic when they have to speak English as they worried about the mistake he/she made. Horwitz et. al. (1986) noted that students are very self-conscious about speaking foreign language infront of the others students, those feeling often lead to fear or even panic. Moreover, according to them, difficulty in speaking in dyads or groups in public are all manifestation of the aspect of anxiety that is communication apprehension

Relatively, from the sixty two students who possessed the introvert dimension of personality, their English speaking anxiety level ranged very high is two students, high is thirty nine students, medium is seventeen students, and low is four students. Then, the extrovert personality dimensions whom possessed by thirty students, the level of English speaking anxiety ranged high is eight students, medium is fifteen students, and low is seven students.

The extrovert students work best in classrooms that allow time for discussion, talking or working with a group. Since they are action oriented, Extrovert students do well with activities involving some type of physical activity. As they are pulled into social life, they may find it difficult to settle down, read, or concentrate on homework. They sometimes find listening 
difficult and need to talk to work out their ideas. According to Purwanto (2007), these introvert students tended to enjoy reading, lectures, and written over oral work. They preferred to work independently and need time for internal processing. They enjoyed listening to others talk about a topic while privately processing the information. Introverts may encounter difficulty with instructors who speak quickly without allowing time for mental processing. They are often uncomfortable in discussion groups, may find it difficult to remember names, and hesitate to speak up in class.

Purwanto (2007) stated that the extrovert students love to talk, participate, organize, and socialize. They are people of action and therefore can be impatient with slow, tedious jobs and complicated procedures. They prefer to figure out things while they are talking.The extrovert students work best in classrooms that allow time for discussion, talking or working with a group. Since they are action oriented, Extrovert students do well with activities involving some type of physical activity. As they are pulled into social life, they may find it difficult to settle down, read, or concentrate on homework. They sometimes find listening difficult and need to talk to work out their ideas.

\section{CONCLUSION}

The writer would like to point out some conclusions. First, from the English speaking anxiety result, students' English speaking anxiety is high level range. Secondly, introvert is the dominant personality dimension possessed by the students. The students' English speaking anxiety based on personality traits at the fifth grade students of Madrasah Ulumul Qur'an Langsa caused by students' belief, incomprehensible input, scare to be laughed by other and speaking infront of the class, lacks of preparation for 
the speaking test/lesson. The teacher or lecturer should also try to accommodate and facilitate the students based on their preferred learning styles.

\section{REFERRENCE}

Basic, L. (2011). Speaking Anxiety: An obstacle to second language learning?, Hogskolan I Gavle. Retrieved from https://www.divaportal.org/smash/get/diva2:453921/fulltext01.pd

Brown, H. D.(2000).Principles of Language Learning and Teaching Fourth Edition. San Fransisco: State University Longman. Inc.

Chan, D. Y. and Wu, G. (2004). A study of foreign language anxiety of EFL Elementary School Students in Taipei county. Journal of National Taipei Teachers College,17 (2). 287-320.

Crosta, P. (2017). What is Anxiety symptoms and causes. Retrieved from

Friedman, H. S. and Schustack, M. W. (2008). Kepribadian: Teori Klasik dan Riset Modern ( $3^{\text {rd }}$ ed.). Jakarta: Erlangga.

Hersen, M. \& Thomas, J. C. (2006). Comprehensive handbook of personality and Psychopathology. Canada: John Wiley \& Sons.

Horwits, E. K. (2017). Anxiety in learning a language. Retrieved from

Horwitz, E. K., Horwitz, M. B. \& Cope, J. (1986). Foreign language classroom anxiety. The Modern Language Journal, 70(2),125-132. Advance online publication. DOI: 10.2307/327317. Retrieved from https://www.jstor.org/stable/327317?origin=JSTOR-

pdf\&seq $=1 /$ subjects

http://mimrepost.com/health/anxiety-in-learning-a-language.htm.

http://www.medicalnewstoday.com/info/anxiety/ 
Jin, Y. (2015). The anxiety-proficiency relationship and the stability of anxiety: The Case of Chinese University Learners of English and Japanese. SSLLT.

Marwan, A. (2007). Investigating students' foreign language anxiety. Malaysian Journal of ELT Research, 3.

Purwanto, N.(2007). Psikologi pendidikan. Bandung: Remaja Rosdakarya.

Stelmach, G. E. \& Vroon, P. A. (1991). Ralfschwarzer's Type writer in advances in Psycology 21: The self in Anxiety, Stress, and Deppression. Amsterdam: Elsevier Science Publishers.

Sukmadinata, N. S.(2007).Landasan Psikologis Proses Pendididkan.Bandung: Permata Rosdakarya. 